\title{
Recent Books Livres récents
}

Katherine O. Acheson, ed. The Diary of Anne Clifford, 1616-1619: A Critical Edition. New York: Garland, 1995.

Raymond A. Anselment. The Realms of Apollo: Literature and Healing in Seventeenth-Century England. Newark: University of Delaware Press/London: Associated University Presses, 1995.

Frank Ardolino. Apocalypse and Armada in Kyd's Spanish Tragedy. Kirksville, Missouri: Sixteenth Century Essays and Studies, 1995.

Bryan Crockett. The Play of Paradox: Stage and Sermon in Renaissance England. Philadelphia: University of Pennsylvania Press, 1994.

Normand Doiron. L'art de voyager: le déplacement à l'époque classique. Sainte-Foy/ Paris: Presses de l’Université Laval/Klincksieck, 1995.

William E. Engel. Mapping Mortality: The Persistence of Memory and Melancholy in Early Modern England. Amherst: University of Massachusetts Press, 1995.

Desiderius Erasmus. Collected works 50: Paraphrase on Acts, ed. John J. Bateman, trans. Robert D. Sider. Toronto: University of Toronto Press, 1995.

Claire Farago, ed. Reframing the Renaissance: Visual Culture in Europe and Latin America, 1450-1650. New Haven: Yale University Press, 1995.

Alison Findlay. Illegitimate power: Bastards in Renaissance Drama. Manchester: Manchester University Press, 1995. 
98 / Renaissance and Reformation / Renaissance et Réforme

W. Th. M. Frijhoff \& M. Spies, eds. Drukkers, boekverkopers en lezers in Nederland tijdens de Republiek. The Hague: SDU Uitgevers, 1995.

Carol F. Hefferman. The Melancholy Muse: Chaucer, Shakespeare and Early Medicine. Ithaca: Duquesne University Press, 1995.

Craig A. Monson. Disembodied Voices: Music and Culture in an Early Modern Italian Convent. Berkeley: University of California Press, 1995.

Steven Mullaney. The Place of the Stage: License, Play, and Power in Renaissance England. Ann Arbor: University of Michigan Press, 1995.

Daniel Murphy. Comenius: A Critical Reassessment of his Life and Work. Dublin: Irish Academic Press, 1995.

Paul R. Rovang. Refashioning "Knights and Ladies Deeds": The Intertextuality of Spenser's Faerie Queene and Malory's Morte Darthur. Cranbury: Farleigh Dickinson University Press, 1995. 